\title{
GENETIC DIVERSITY OF LACTOBACILLI ISOLATED FROM HUMAN INFANT FECES*
}

\author{
MAGALI SOARES DOS SANTOS POZZA** \\ LÚCIA HELENA DA SILVA MIGLIORANZA*** \\ JOSÉ EDUARDO GARCIA**** \\ PAULO CESAR POZZA***** \\ ROBERTA MERGUIZO******
}

\begin{abstract}
Seventy-five strains isolated from fecal samples of six children were studied for their morphology and biochemical properties. Genetic diversity of 30 strains was analyzed by using Random Amplified Polymorphic DNA (RAPD). The intestinal isolates were grouped into four clusters. Some strains in group I were $100 \%$ similar (Lactobacillus reuteri) while high degree of genetic diversity was found in groups II (standard species), III and IV. Eight strains of group I and group III were identified through biochemical identification, as Lactobacillus reuteri, Lactobacillus acidophilus, Lactobacillus plantarum, Lactobacillus casei and Lactobacillus salivarius, and showed low genetic similarity with type strains. The findings in this study provide a strong basis for exploring the potential of these eight selected lactobacilli strains for use in fermented-milk based products.
\end{abstract}

KEY-WORDS: BACTERIA IDENTIFICATION; LACTIC ACID BACTERIA; Lactobacillus plantarum; PCR; PROBIOTICS; RAPD.

\footnotetext{
Financiado pela Fundação Araucária de Apoio ao Desenvolvimento Científico e Tecnológico do Paraná. Parte do trabalho de tese de doutorado desenvolvido pelo primeiro autor.

** Doutora em Ciência de Alimentos, Professora, Centro de Ciências Agrárias, Universidade Estadual do Oeste do Paraná (UNIOESTE), Campus Marechal Cândido Rondon, Paraná (e-mail: magaspozza@ hotmail.com).

*** Doutora em Ciência de Alimentos, Professora, Centro de Ciências Agrárias, Departamento de Tecnologia de Alimentos e Medicamentos, Universidade Estadual de Londrina, Perobal, PR (e-mail: luciah@uel.br).

**** Doutor em Biologia (Genética), Professor, Centro Acadêmico de Vitória, Universidade Federal de Pernambuco, Vitória de Santo Antão, PE (e-mail: jegarcia30@gmail.com).

***** Doutor em Nutrição de Monogástricos, Professor, Universidade Estadual de Maringá, Maringá, PR (e-mail: pcpozza@hotmail.com).

****** Química, graduada pela Universidade Estadual de Londrina, Londrina, PR (e-mail: romerguizo@yahoo. com.br).
} 


\section{INTRODUCTION}

The increasing interest in healthy lifestyle has led to the use of probiotic in a variety of fermented milk products (FUJIMOTO et al., 2008). Lactobacillus strains are the most widely used probiotics, and there are many reports of their benefits to human health (WOLD, 2001).

Lactobacilli have been isolated from different sources, for several purposes, like preparation of naturally fermented products such Italian salami (MACIEL et al., 2003) or meat (OLIVEIRA, OLIVEIRA \& GLÓRIA, 2008) and meat products, such as sausage (SAWITZKI et al., 2007). Few studies have been published describing the isolation of Lactobacilli from the human (RYAN et al., 2008) and other species gastrointestinal tract (McCOY \& GILLILAND, 2007; RODRIGUEZ-PALACIOS et al., 2009).

Lactobacilli are Gram positive rods belonging to the group of lactic acid bacteria (LAB) (BERNARDEAU, 2008). They are ubiquitous in the diet and are found in the gastrointestinal tract soon after birth. In healthy humans, lactobacilli are normally present in the oral cavity $\left(10^{3}-10^{4} \mathrm{cfu} / \mathrm{g}\right)$, in the ileum $\left(10^{3}-10^{7} \mathrm{cfu} / \mathrm{g}\right)$ and in the colon $\left(10^{4}-10^{8} \mathrm{cfu} / \mathrm{g}\right)$, and are the dominant microorganism in the vagina (MERK et al., 2005).

The subsequent development of gut microflora during infancy is a complex succession of bacterial species. Among intestinal bacterial species, lactic acid bacteria and bifidobacteria are considered particularly important for their health-promoting benefits such as the prevention of gut colonization by pathogens (McFARLAND, 2000).

The traditional phenotypic lactobacilli identification mainly based on cell morphological characteristics and sugar fermentation profiles are still widely applied on a routine basis, but a reliable identification of members from these species is complex by strictly phenotypical testing, which is often highly unsatisfactory (VENTURA \& ZINK, 2002 ).

Although useful for identification purposes, biochemical characterization has poor discriminating capacity and molecular techniques must be used for typing purposes. High-resolution genotypic techniques such as random amplified polymorphic DNA (RAPD) and amplified fragment length polymorphism (AFLP) are often used to generate species-specific eletrophoretic profiles when investigating the genetic diversity between Lactobacillus species. The identification of Lactobacillus species is an important step not only in the development of new and interesting cultures, but also in the identification at intra-species level (McLEOD et al., 2008).

RAPD wide popularity can be attributed mainly to the fact that it is rapid, easy and does not require any prior knowledge of the target sequence; being also universally applicable to any genome. In principle, RAPD involves random amplification from the target bacterial genome with the aid of a single primer under less stringent conditions (SESENÃ, SÁNCHEZ \& PALOP, 2004).

The combination of techniques, both biochemical and molecular ones can assure a better identification of isolated strains. Taking that into consideration, the goal of this research was to select potential probiotics amongst isolated strains from children feces using biochemical tests and RAPD technique.

\section{MATERIAL AND METHODS}

This research was carried out in the Science, Technology, Biochemistry and Biotechnology, both in the State University of Londrina (Universidade Estadual de Londrina), Brazil. The strains were obtained from children's feces (both genders). The children were one year old, previously diagnosed as healthy, not submitted to antibiotic therapy. The samples were collected during the months of November and December 2004, at the Day Care Center of the State University of Londrina.

Fecal samples from six children were collected using swab (KONEMAN, ALLENS \& 
DOWELL, 1997). The swab was placed in $10 \mathrm{~mL}$ of Rogosa broth BBL TM LBS broth (DIFCO, USA) and incubated at $37^{\circ} \mathrm{C}$ for 24 hours. Lactobacillus strains were grown on MRS agar (DE MAN, ROGOSA \& SHARPE, 1960) (Himedia, Mumbai, India). Representative colonies were isolated from MRS plates of the highest sample dilutions. All colonies were picked out from plates containing less than 10 colonies and only some colonies were randomly selected from those plates containing more than 10 colonies. The purity degree of isolates was checked by streaking and sub culturing on fresh MRS broth as well as MRS agar, followed by microscopic examinations. Identified strains of Lactobacillus were preserved in MRS broth using $15 \%(\mathrm{v} / \mathrm{v})$ glycerol at $-20^{\circ} \mathrm{C}$.

The primary classification was based on results obtained from Gram staining, cell morphology and catalase tests, being identified based on phenotypic properties such as carbon dioxide production from glucose (FRAZIER, MARTH \& DEIBEL, 1968), growth at different temperatures and sugar fermentation patterns.

The ability of strains to grow at different temperatures was evaluated using tubes containing $10 \%$ of reconstituted skim milk and incubated at $15^{\circ} \mathrm{C}$ for 3 and 10 days, at $37^{\circ} \mathrm{C}$ for 2 days and at $45^{\circ} \mathrm{C}$ for 3 days (BERGEY et al., 1986).

The ability of microorganisms to metabolize carbohydrates was verified using modified MRS broth and adding $2 \%$ of the carbohydrate being tested dextrose, fructose, galactose, lactose, maltose, mannose, rhamnose, saccharose, sorbitol and xylose, and bromocresol purple $(0.004 \%$ weight/volume) as indicator, following incubation at $37^{\circ} \mathrm{C}$ for $48 \mathrm{~h}$. The positive results were interpreted by the change in the indicator color from purple to yellow (DAVIS, 1995).

The Lactobacillus strains used for comparative purposes (reference strains) in the molecular analyses were obtained from the following Cultures Collection: Lactobacillus acidophilus (Korean Collection for Type Cultures - KCTC 3111), Lactobacillus casei (KCTC 1121), Lactobacillus rhamnosus (KCTC 3237/ ATCC 7469), (ATCC- American Type Culture Collection) Lactobacillus johnsoni (KCTC 3138/ ATCC 332), Lactobacillus paracasei (KCTC 3510), Lactobacillus brevis (00221/ATCC 367), Lactobacillus fermentum (00225/ATCC 9338), Lactobacillus plantarum (00007/ ATCC 8014), Lactobacillus acidophilus ( La-5 ${ }^{\mathrm{TM}}$ ) and Lactobacillus casei ( $\left.\mathrm{LC}-01^{\mathrm{TM}}\right)$ and Lactobacillus helveticus ${ }^{\mathrm{TM}}$ (Christian Hansen-Valinhos, Brazil).

The procedure for DNA extraction from Lactobacillus ssp. strains was according to methodology of Luchansky, Tennant \& Klaenhammer (1991) with minor modifications. Briefly, cells from an overnight culture, previously grown at $37^{\circ} \mathrm{C}$ in $100 \mathrm{~mL}$ of MRS broth, were collected by centrifugation and resuspended in $200 \mathrm{~mL}$ of fresh MRS broth. The cells were harvested by centrifugation, washed twice in TES buffer $(50 \mathrm{mmol} \mathrm{NaCl}$ - Vetec, $30 \mathrm{mmol}$ Tris $\mathrm{pH} 8.0$ and $5 \mathrm{mmol}$ EDTA), and resuspended in $0.5 \mathrm{~mL}$ of lysis buffer (50 mmol Tris pH 8.0, $1.0 \mathrm{mmol}$ EDTA; $20 \%$ sucrose - Vetec) containing mutanolysin $(4.0 \mu \mathrm{g} \mathrm{mL}$ - Invitrogen) and RNase $(44 \mu \mathrm{L} / 18 \mathrm{~mL}$ bufferInvitrogen). This mixture was incubated at $37^{\circ} \mathrm{C}$ for $45 \mathrm{~min}$. A $200 \mu \mathrm{L}$ volume of sodium dodecyl sulphate $20 \%$ was added, and the mixture was incubated at $65^{\circ} \mathrm{C}$ until the solution cleared. After the addition of $20 \mu \mathrm{L}$ of proteinase $\mathrm{K}$ and $15 \mathrm{~min}$ of incubation at $65^{\circ} \mathrm{C}$, the lysate was extracted twice with phenol:chloroform (25:24) $(700 \mu \mathrm{L}$ sample) and once with chloroform (500 $\mu \mathrm{L}$ sample). Ethanol $95 \%$ was used to precipitate and ethanol $70 \%$ to wash the DNA. The samples were kept at $37^{\circ} \mathrm{C}$ for $1 \mathrm{~h}$, followed by the addition of TE $(10 \mathrm{mmol} / \mathrm{L}$ Tris $\mathrm{pH} 8.0$ and $1.0 \mathrm{mmol} / \mathrm{L}$ EDTA $)$ and DNA was incubated overnight at $37^{\circ} \mathrm{C}$.

RAPD analyses were carried out in a $10 \mu \mathrm{L}$ final volume, containing $5 \mathrm{ng}$ DNA template, $0.4 \mathrm{mmol} / \mathrm{L}$ primer, $200 \mu \mathrm{M}$ of each dNTP's, $1.5 \mathrm{mmol} / \mathrm{L} \mathrm{MgCl}_{2}$ and $1 \mathrm{U}$ Taq DNA polymerase (Invitrogen, Brazil) in $20 \mathrm{mmol} / \mathrm{L}$ Tris- $\mathrm{HCl} \mathrm{pH} 8.4$ containing $50 \mathrm{mmol} / \mathrm{L} \mathrm{KCl}$. The primers used were W5, X4, W2, W4, W20, W11, W19, X3, X5, X9, X13, X14, X12, W14, W6, X9 (Operon Technologies, Alameda, CA, USA) (Table 1). The thermal cycling was programmed for 40 cycles of $40 \mathrm{~s}$ at $92^{\circ} \mathrm{C}$, $1 \mathrm{~min}$ and $30 \mathrm{~s}$ at $40^{\circ} \mathrm{C}$ and $2 \mathrm{~min}$ at $72^{\circ} \mathrm{C}$ with a final extension of $5 \mathrm{~min}$ at $72^{\circ} \mathrm{C}$ and $10 \mathrm{~min}$ at $10^{\circ} \mathrm{C}$. PCR products were resolved in $2 \%$ agarose gels in TBE $(89 \mathrm{mmol} / \mathrm{L}$ Tris base, $89 \mathrm{mmol} / \mathrm{L}$ boric 
acid, $0.2 \mathrm{mmol} / \mathrm{L}$ EDTA) and stained with ethidium bromide under UV light. All the reactions were performed twice and negative controls were used at all times.

TABLE 1 - PRIMER SEQUENCES USED IN THIS STUDY

\begin{tabular}{ll}
\hline Primers & Sequences 5 $^{\prime}-$ 3 $^{\prime}$ \\
\hline $\mathrm{W}-02$ & ACCCCGCCAA \\
\hline $\mathrm{W}-04$ & CAGAAGCGGA \\
\hline $\mathrm{W}-05$ & GGCGGATAAG \\
\hline $\mathrm{W}-06$ & AGGCCCGATG \\
\hline $\mathrm{W}-14$ & CTGATGCGTG \\
\hline $\mathrm{W}-19$ & CTGCTGAGCA \\
\hline $\mathrm{W}-20$ & CAAAGCGCTC \\
\hline $\mathrm{X}-03$ & TGTGGCAGCA \\
\hline $\mathrm{X}-04$ & TGGCGCAGTG \\
\hline $\mathrm{X}-05$ & CCGCTACCGA \\
\hline $\mathrm{X}-09$ & CCTTTCCCTC \\
\hline $\mathrm{X}-12$ & GGTCTGGTTG \\
\hline $\mathrm{X}-13$ & TCGCCAGCCA \\
\hline $\mathrm{X}-14$ & ACGGGAGCAA \\
\hline
\end{tabular}

Only reproducible well-marked amplified fragments were scored. For each genotype, the presence and absence of fragments were recorded as 1 or 0 . A pairwise comparison of banding patterns was evaluated by the Jaccard similarity coefficient (SNEATH \& SOKAL, 1973) using the NTSYS-PC analysis software (ROHLF \& NTSYS, 1987). The cluster analysis was performed using the Unweighted Pair Group Method with Arithmetic Mean (UPGMA).

\section{RESULTS}

The 75 isolated colonies were presented as Gram positive, mostly bacilli (cocci-bacilli, long and thin bacilli) and rarely cocci. The predominance of Gram positive rod-shaped bacilli was verified. Thirty isolates have been previously selected according to cell morphology (bacilli or rows), catalase reaction (negative) and spore production (non-spore formers). All lactobacilli were tested for their ability to ferment carbohydrates (Table 2), including D-xylose, which is typically fermented by $L$. pentosus.

Six carbohydrates were fermented by all strains within 24-48h. The thirty strains did not ferment D- xylose and some strains showed weak positive or negative reaction with rhamnose (29 strains), sorbitol (17 strains) and saccharose (6 strains) as the only carbohydrate source.

According to the identification tables of Bergey's manual of systematic bacteriology (BERGEY, 1986) it was observed that 11 isolates $(36.6 \%)$ had metabolic behavior similar to $L$. reuteri. The sugar profile of the other strains suggested that these strains belong to $L$. casei, $L$. plantarum, $L$. brevis, $L$. salivarius $L$. fermentum, $L$. rhamnosus and $L$. gasseri species. Some researchers identified that $L$. paracasei ssp. paracasei, L. rhamnosus, L. acidophilus, L. gasseri and $L$. reuteri were isolated 
from children's feces. The present study findings were similar to those of Xanthopoulos, LitopoulouTanetaki \& Tzanetakis (2000).

TABLE 2 - ISOLATE PHENOTYPIC CHARACTERIZATION

\begin{tabular}{llll}
\hline Isolate & Phenotypic affiliation & Isolate & $\begin{array}{l}\text { Phenotypic } \\
\text { affiliation }\end{array}$ \\
\hline 1.2 & L. gasseri & 4.1 & L.reuteri / L. fermentum \\
2.2 & L. fermentum & 4.6 & L.reuteri/ L. fermentum \\
2.3 & L. fermentum & 4.3 & Nd \\
2.5 & L. acidophilus & 5.2 & L.casei/ L. plantarum \\
2.11 & L. acidophilus & 5.3 & L. casei/ L. plantarum \\
2.15 & L.reuteri & 5.6 & L. plantarum \\
2.16 & L.reuteri & 5.5 & L.. plantarum /L. paracasei \\
2.17 & L.reuteri & $5.7^{*}$ & L. brevis \\
2.19 & L.reuteri & 5.8 & L. salivarius /L. plantarum/ \\
2.21 & L.reuteri & 5.9 & L. casei \\
2.22 & L.reuteri & 6.7 & L. casei \\
3.2 & L.casei & 6.8 & L. brevis \\
3.3 & L.reuteri/ L. casei & 6.5 & L. acidophilus /L. salivarius \\
3.7 & L.reuteri/ L. casei & 6.9 & L. rhamnosus /L. salivarius \\
3.14 & L.reuteri/ L. casei & 6.10 & L. salivarius /L. acidophilus \\
\hline
\end{tabular}

*undetermined; but sorbitol +.

The selected strains had different growth response and biochemical profile at different temperatures. According to the growth temperature, 2.5 and 2.11 could belong to the $L$. acidophilus group (BERGEY, 1986).

The RAPD results showed the existence of genetic differences between strains. Amongst the 16 primers used, six (OPW 14 and 16, OPX 9, 12, 13 and 14) were efficient in the amplification of the samples, generating a total of 110 polymorphic bands. The UPGMA dendrogram generated (Figure 1) and the band pattern relationships between some representative reference strains and isolates were analyzed.

The $17.5 \%$ similarity between strains from Chr. Hansen and ITAL for L. acidophilus was considered low, and a $34.8 \%$ similarity for $L$. casei types was verified. Comparing the standard strains from the same species, Nigatu (2006) and Sesenã, Sánchez \& Palop (2004) also reported different clusters and did not find an explanation for the phenomenon but they verified higher variability. 


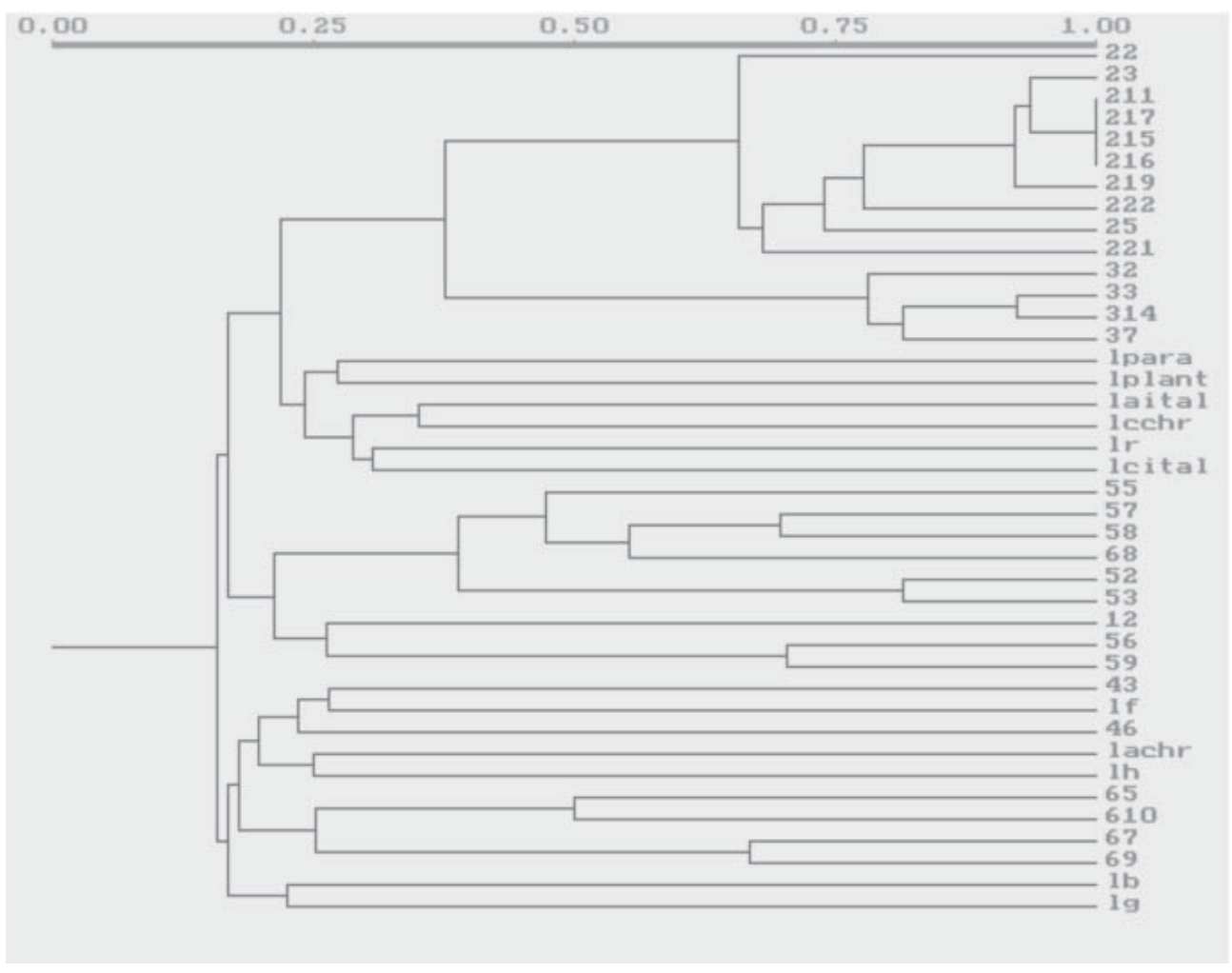

\section{FIGURE 1 - DENDOGRAM OF GENETIC SIMILARITY USING THE JACCARD COEFFICIENT AND UPGMA METHOD FOR THE ISOLATED INTESTINAL BACTERIA, APPLYING RAPD TECHNIQUE}

Note: Sequence: 2.2, 2.3, 2.11, 2.17, 2.15, 2.16, 2.19, 2.22, 2.5, 2.21, 3.2, 3.3, 3.14, 3.7, L. paracasei, L. plantarum, L. acidophilus Ital, L. casei (Chr. Hansen- Lc 01 ${ }^{\mathrm{TM}}$ ), L. reuteri, L. casei- ITAL, 5.5, 5.7, 5.8, 6.8, 5.2, 5.3,1.2, 5.6, 5.9, 4.3, L. fermentum, 4.6, L. acidophilus (Chr. Hansen- La - $5^{\mathrm{TM}}$ ), L. helveticus, 6.5, 6.10, 6.7, 6.9, L. brevis and L. johnsoni.

The RAPD methodology for characterization of Lactobacillus strains, isolated from the human intestinal tract, is considered a complementary alternative to traditional systematic methods. There was concordance between both methodologies used in this experiment, and the dendrogram obtained (Figure 1) demonstrated a clear presence of four distinct groups.

Group I had low variability and was formed by 14 strains, from 2.2 to 3.7 . These results agree with those obtained by biochemical tests, because some of the strains could belong to the same specie (L. reuteri). Strains 2.11, 2.15, 2.16 and 2.17 were $100 \%$ similar, although 2.11 had been previously classified as $L$. acidophilus.

Group II was formed by standard L. paracasei, L. plantarum, L. acidophilus (ITAL), L. casei (Chr. Hansen Lc 01 ${ }^{\mathrm{TM}}$ ), L. rhamnosus and L. casei (ITAL) species, since they had common characteristics, possibly because some strains have been selected for presenting an active metabolism in the gastrointestinal tract. These results demonstrated that the RAPD technique allows the differentiation between several species of Lactobacillus, since they presented low similarity, although the two standards of $L$. casei were in the same cluster.

In group III, strains 5.2, 5.3, 5.5, 5.7, 5.8 and 6.8 were in the same cluster and the similarity was around $27 \%$. Some of these isolates were classified as belonging to the same group, according to the Bergey's manual of systematic bacteriology (1986). They had high similarity in the carbohydrate metabolism, besides the fact that they are facultative heterofermentative bacteria. It was also observed that the isolates had only $16.8 \%$ of similarity and $16.2 \%$ with the standard strains (L. plantarum and L. casei). 
Group IV, which contained standard L. fermentum, L. acidophilus (Chr. Hansen - La-5 ${ }^{\mathrm{TM}}$ ) and $L$. helveticus, also showed high polymorphism.

\section{DISCUSSION}

In spite of this study results demonstrated a concordance between the biochemical and molecular species identification or grouping, the RAPD clusters did not correspond to the API $50 \mathrm{CH}$ grouping pattern of isolates showed in the experiment carried out by Nigatu (2006), who used 42 lactobacilli isolated from tef and koncho, when compared with 30 types of strains. This inconsistency between the results observed at the two methodologies should be explained by the great plasmidial mobility in this group of bacteria, once the most carbohydrate fermentation ability is plasmid-encoded.

Nishitani et al. (2004) evaluated 45 Lactobacillus strains isolated from human feces and fermented products by RAPD and verified conflicting results when compared to the PCR identification (16S $23 S$ rDNA spacer regions) because they found species related to $L$. plantarum such as $L$. paraplantarum and $L$. pentosus. The authors grouped these strains into 4 clusters, A, B, C and D, and verified low similarity between them, around $40 \%$, and that these clusters were not speciesspecific. However, 10 out of the 14 strains from humans were included in the same cluster and 8 strains presented low similarity with any of the other clusters, indicating that RAPD is a useful tool to distinguish related Lactobacillus species.

Using RAPD PCR, Wall et. al (2007) evaluated 292 isolates obtained from adult and infant stool samples and verified prevalence of $L$. gassei and $L$. salivarius among the Lactobacillus species found in samples collected from infants.

A study carried out by Ahrné et al. (2006) used RAPD to identify Lactobacillus species from children's feces with 1, 2, 4 and 8 weeks of age and with 6,12 and 18 months. The authors considered that, when the strains from the same child showed the same band profile in the RAPD analysis, they were considered as belonging to the same species. The following Lactobacillus species were identified: L. rhamnosus, L. paracasei, L. gasseri, L. fermentum, L. reuteri, L. plantarum, $L$. delbrueckii and $L$. salivarius. Using the same parameter to this study data, it is possible to consider the isolates $2.11,2.15,2.16$ and 2.17 as the same species in spite of the isolate 2.11 was classified as $L$. acidophilus by the biochemical tests. A more sensitive method, like ARDRA for example, have to be used aiming to perform the correct identification of this isolate.

The species diversity observed can be compared to those obtained by Marzotto et al. (2006) that used PCR-DGGE to characterize more than 150 lactobacilli isolates at different sampling times from feces of infants who received $L$. paracasei $A$. Those analyses revealed the complex (16 species) and varied composition of the Lactobacillus community, which contained typical intestinal species (L. ruminis, L. reuteri, L. rhamnosus and L. gasseri), as well as food-associated species ( $L$. paracasei, L. plantarum, L. fermentum). The variability was observed among the species isolated throughout the experiment, though $L$. casei/L. paracasei was found as the prevalent species $(43 \%$ to the isolates). Finding food-associated species in the analyzed samples indicates a promising future for testing these isolates to be used as probiotics lineages.

Albesharat et al. (2011) isolated LAB from 70 different samples (15 infants, 15 adults, 15 breast milk and 25 fermented foods) and verified diversity of RAPD types found in food versus human samples. Such findings suggest the relevance of host factors in colonization and individual host specificity and support the hypothesis that there is a vertical transfer of intestinal LAB to the mother's gut to her milk, and subsequently through the milk to the infants gut.

Fujimoto et al. (2008) evaluated the ability of $L$. casei (LCS) to proliferate in human intestines after being ingested and developed a PCR-based method to identify and quantify LcS using specific primer set (pLcS) derived from a randomly amplified polymorphic DNA (RAPD) analysis. They tested a total of 27 RAPD primers and the primer p1252 generated a $0.7 \mathrm{~kb}$ LcS- specific band. 
In infant feces, the presence of $L$. salivarius CECT 5713 , strain originally isolated from feces of a breast-fed infant, has been observed by Martin et al. (2006) using RADP analysis Kit. Later, species-specific PCR showed that $L$. salivarius were present in the milk from the respective mother. The found of four suspect $L$. salivarius lineages in the present study sample should be explained by the same way, but it was also observed a high degree of genetic dissimilarity between those lineages. Three of them grouped at the cluster IV $(6.5,6.9$ and 6.10$)$ with low genetic similarity and one (5.8) clustered out of this group demonstrating a high genetic diversity at this species. A more sensitive method for species identification will be used at these lineages at the continuing of this research with the aim to confirm these observations.

As previously reported in literature, RAPD-PCR has proven to be a successful technique for recognizing unique sequences for a selected strain, especially due to its ability to detect differences between bacteria at genomic level (VENTURA \& ZINK, 2002). Although a simple and rapid method, RAPD is prone to poor reproducibility in the band pattern due to the present small changes in the reaction conditions. The time saved by the direct application of RAPD is often lost in achieving consistency and in confirming the reproducibility of the results. This standardization of the best resolving conditions and maintenance of very high consistency in all parameters are considered the most important aspects in applying RAPD (SINGH et al., 2009).

The eight lineages identified as $L$. reuteri, L. gasseri, L. casei, L. plantarum, L. crispatus, $L$. salivarius, $L$. rhamnosus and $L$. acidophilus in the analyzed samples are considered strong candidates to the continuance of this research, in which is intended to submit them to a molecular characterization with 16S rRNA ARDRA method using it to develop a fermented milk beverage with probiotic characteristics.

\section{CONCLUSION}

The strains were grouped into four clusters and one of these clusters had good concordance with the biochemical data. Results obtained by this study provide bases to explore the potential of those eight selected lactobacilli strains regarding its usage in fermented products.

\section{RESUMO}

\section{DIVERSIDADE GENÉTICA DE LACTOBACILOS ISOLADOS DE FEZES DE CRIANÇAS}

Setenta e cinco cepas isoladas de fezes de seis crianças foram estudadas quanto a sua morfologia e propriedades bioquímicas. Analisou-se a diversidade genética de 30 cepas pelo método Random Amplified Polymorphic DNA (RAPD). Os isolados intestinais foram agrupados em quatro clusters. Algumas estirpes do grupo I mostraram-se 100\% similares (Lactobacillus reuteri). Encontrou-se alto grau de diversidade genética nos grupos II (cepas de referência), III e IV. Oito cepas dos grupos I e III foram identificadas bioquimicamente, como Lactobacillus reuteri, Lactobacillus acidophilus, Lactobacillus plantarum, Lactobacillus casei e Lactobacillus salivarius, as quais mostraram baixa similaridade genética com as estirpes padrões. Os resultados obtidos neste estudo proporcionam bases para explorar o potencial dessas oito estirpes de lactobacilos selecionadas para uso em produtos fermentados.

PALAVRAS-CHAVE: IDENTIFICAÇÃO DE BACTÉRIAS; BACTÉRIAS ÁCIDO LÁTICAS; Lactobacillus plantarum; PCR, PROBIÓTICOS; RAPD.

\section{REFERENCES}

1 AHRNÉ, S.; LONNERMARK, E.; WOLD, A.E.; ABERG, N.; HESSELMAR, B.; SAALMAN, R.; STRANNEGARD, I.; MOLIN, G.; ADLERBERTH, I. Lactobacilli in the intestinal microbiota in Swedish infants. Microbes and Infection, v. 7, p.12561262,2006

2 ALBESHARAT, R.; EHRMANN, M.A.; KORAKLI, M.; YAZAJI, S.; VOGEL, R. Phenotipic and gentotipic analyses of lactic acid bacteria in local fermented food breast milk and faeces of mothers and their babies. Systematic and Applied Microbiology, v. 34, p. 148-155, 2011. 
3 BERNARDEAU, M; VERNOUX, J. P.; HENRI-DUBERNET, S.; GUÉGUEN, M. Safety assessment of dairy microorganisms: the Lactobacillus genus. International Journal of Food Microbiology, v. 126, p. 278-285, 2008.

4 BERGEY, D.H.; SNEATH, P.H.A.; MAIN, S.N.; SHARPE, M.E.; HOLTH, J.E. Bergey's manual of systematic bacteriology. Baltimore: Wiliams and Wilkins, 1986. 1599 p.

5 DAVIS, G.H. The classification of lactobacilli from the human mouth. Journal of General Microbiology, v.13, p.481-493, 1995.

6 DE MAN, J.C.; ROGOSA, M.; SHARPE, M.E. A medium for the cultivation of lactobacilli. J. Applied Bacteriol., v. 23, p. $130-135,1960$.

7 FRAZIER, W.C.; MARTH, E.H.; DEIBEL, R.M. Laboratory manual for food microbiology. $4^{\text {th }}$ ed. Minneapolis, Minnesota: Burgess Publishing, 1968.

8 FUJIMOTO, J.; MATSUKI, T.; SASAMOTO, M.; TOMII, Y.; WATANABE, K. Identification and quantification of Lactobacillus casei strain Shirota in human feces with strain-specific primers derived from randomly amplified polymorphic DNA. International Journal of Food Microbiology, v.126, p. 210-215, 2008.

9 KONEMAN, E.; ALLENS, S.; DOWELL, V. Color atlas and textbook of diagnostic microbiology. $5^{\text {th }}$ ed. Nova York: Lippincott, 1997. $321 \mathrm{p}$.

10 LUCHANSKY, J. B.; TENNANT, M. C.; KLAENHAMMER, T. R. Molecular cloning and DNA polymorphisms in Lactobacillus acidophilus and L. gasseri. Journal of Dairy Science, v.74, p. 3293-3302, 1991.

11 MACIEL, J. F.; TEIXEIRA, M. A.; DE MORAES, C. A.; GOMIDE, L. A. D. Antibacterial activity of lactic cultures isolated of Italian salami. Brazilian Journal of Microbiology, v.34, p. 121-122, 2003.

12 MARTIN, R.; JIMENES, E.; OLIVARES, M.; MARÍN, M.L.; FERNÁNDEZ, L.; XAUS, J.; RODRÍGUES, J.M. Lactobacillus salivarius CECT 5713, a potential probiotic strain isolated from infant feces and breast milk of a mother-child pair. International Journal of Food Microbiology, v.112, p.35-43, 2006.

13 MARZOTTO, M.; MAFFERS, C.; PAERNOSTER, T.; FERRANO, R.; RIZOTTI, L.; PELLEGRINO, M.; DELLAGLIO, F.; TORRIANI, S. Lactobacillus paracasei A survives gastrointestinal passage and affects the fecal microbiota of health infants. Research in Microbiology, v.157, p. 857-666, 2006.

14 McCOY S.; GILLILAND S.E. Isolation and characterization of Lactobacillus species having potential for use as probiotic cultures for dogs. J. Food Sci., v. 72, n.3, p.M94-97, Apr. 2007.

15 McFARLAND, L.V. Normal flora: diversity and functions. Microbial Ecology Health Disease, v. 12, p.193-207, 2000.

16 McLEOD, A.; NYQUIST, O.L.; SNIPEN, L.; NATERSTAD, K.; AXELSSON, L. Diversity of Lactobacillus sakei strains investigated by phenotypic and genotypic methods. Systematic and Applied Microbiology, v.31, p. 393-403, 2008.

17 MERK, K.; BORELLI, C.; KORTING, H.C. Lactobacilli-bacteria-host interactions with special regard to the urogenital tract. International Journal of Medical Microbiology, v. 295, p. 9-18, 2005.

18 NIGATU, A. Evaluation of numerical analyses of RAPD and API $50 \mathrm{CH}$ patterns to diferentiate Lactobacillus plantarum, L. fermentum, L. rhamnosus, L. sake, L. parabuchneri, L. gallinarum, L. casei, Weissellla minor and related taxa isolated from koncho and tef. J. Appl. Microbiol., v. 89, p. 969-978, 2006.

19 NISHITANI, Y.; SASAKI, E.; FUJISAWA, T.; OSAWA, R. Genotypic analyses of Lactobacilli with a range of tannase activities isolated from human feces and fermented food. Systematic and Applied Microbiology, v. 27, p. 9-117, 2004.

20 OLIVEIRA, R. B. P.; OLIVEIRA, A. L.; GLÓRIA, M. B. A. Screening of lactic acid bacteria from vacuum packaged beef for antimicrobial activity. Brazilian Journal of Microbiology, v. 39, p. 368-374, 2008.

21 ROHLF, F. J.; NTSYS, P.C. Micro-computer programs for numerical taxonomy and multivariate analysis. Washington: American Statistician, 1987. $330 \mathrm{p}$.

22 RODRIGUEZ-PALACIOS, A.; STAEMPFLI, H.R.; DUFFIELD T.; WEESE, J.S. Isolation of bovine intestinal Lactobacillus plantarum and Pediococcus acidilactici with inhibitory activity against Escherichia coli O157 and F5. J. Appl. Microbiol., v.106, n.2. p.393-401, Feb. 2009.

23 RYAN, K.A.; JAYARAMAN, T.; DALY, P.; CANCHAYA, C.; CURRAN, S.; FANG, F.; QUIGLEY, E.M.; O'TOOLE, P.W. Isolation of lactobacilli with probiotic properties from the human stomach. Lett. Appl. Microbiol., v. 47, n.4, p.269-74, Oct.2008

24 SAWITZKI, M. C.; FIORENTINI, A. M.; BROD, F. C. A.; TAGLIARI, C.; BERTOL, T. M.; ARISI, A. C. M.; SANT'ANNA, E. $\mathrm{S}$. Phenotypic characterization and species-specific PCR of promising starter culture strains of Lactobacillus plantarum isolated from naturally fermented sausages. Brazilian Journal of Microbiology, v. 38, p. 547-552, 2007. 
25 SESENÃ, S.; SÁNCHEZ, I.; PALOP, L. Genetic diversity (RAPD-PCR) of lactobacilli isolated from "Almagro" eggplant fermentations from two seasons. FEMS Microbiology Letters, v.228, p.159-165, 2004.

26 SINGH, S.; GOSWAMI, P.; SINGH, R.; HELLER, R. K. J. Application of molecular identification tools for Lactobacillus, with a focus on discrimination between closely related species: a review. Food Science and Technology, v.42, p.448-457, 2009.

27 SNEATH, P.H.A.; SOKAL, R.R. (Eds.). Numerical taxonomy. San Francisco: Freeman, 1973.

28 VENTURA, M.; ZINK, R. Specific identification and molecular typing analysis of Lactobacillus johnsonii by using PCRbased methods and pulsed-field gel electrophoresis. FEMS Microbiology Letters, v.217, p.141-154, 2002.

29 WALL, R.; FITZGERALD, G.; HUSSEY, S.; RYAN, T.; MURPHY, B.; ROSS, P.; STALON, C. Genomic diversity of cultivable Lactobacillus populations residing in the neonatal and adult gastrointestinal tract. FEMS Microbiology Ecology, v. 59, n.1, p. 127-337, 2007

30 WOLD, A.E. Immune effects of probiotics. Scand. Journal Nutrition, v.45, p. 76-85, 2001.

31 XANTOPHOULOS, V.; LITOPOULOU-TANETAKI, E.; TZANETAKIS, N. Characterization of Lactobacillus isolates from infant faeces as dietary adjuncts. Food Microbiology, London, v.17, p.205-215, 2000.

\section{Aknowledgements}

The authors would like to thank the Araucária Foundation (Fundação Araucária)/ State of Paraná/BRAZIL for the financial support to this work, and CAPES Research Agency for ProDoc Fellowship to Dr. J.E. Garcia. 